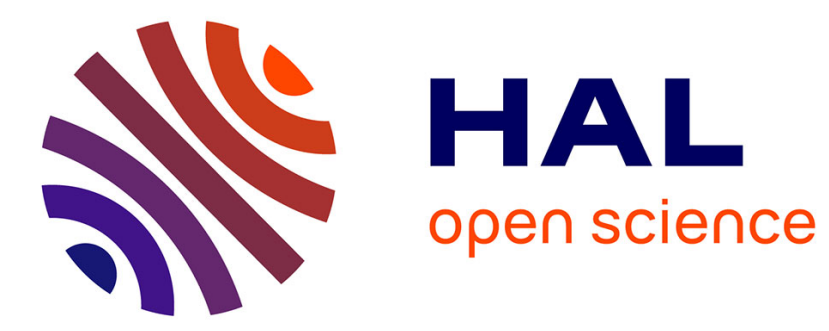

\title{
Heuristic Inspection to Assess Persuasiveness: A Case Study of a Mathematics E-Learning Program
}

Eric Brangier, Michel Desmarais

\section{To cite this version:}

Eric Brangier, Michel Desmarais. Heuristic Inspection to Assess Persuasiveness: A Case Study of a Mathematics E-Learning Program. Design, User Experience and Usability, 2014. halshs-02571802

\section{HAL Id: halshs-02571802 \\ https://shs.hal.science/halshs-02571802}

Submitted on 13 May 2020

HAL is a multi-disciplinary open access archive for the deposit and dissemination of scientific research documents, whether they are published or not. The documents may come from teaching and research institutions in France or abroad, or from public or private research centers.
L'archive ouverte pluridisciplinaire HAL, est destinée au dépôt et à la diffusion de documents scientifiques de niveau recherche, publiés ou non, émanant des établissements d'enseignement et de recherche français ou étrangers, des laboratoires publics ou privés. 


\title{
Heuristic Inspection to Assess Persuasiveness: A Case Study of a Mathematics E-Learning Program
}

\author{
Eric Brangier * and Michel C. Desmarais ** \\ * Université de Lorraine - Metz, PErSEUs EA 7312, Psychologie Ergonomique et Sociale pour \\ l'Expérience Utilisateurs - BP 30309 Île du Saulcy - 57006 Metz (France). \\ ** Polytechnique Montréal, Département de génie informatique et génie logiciel, C.P. 6079, \\ succ. Centre-Ville, Montréal, Québec H3C 3A7 (Canada). \\ Eric.Brangier@univ-lorraine.fr \\ michel.desmaraisepolymtl.ca
}

\begin{abstract}
This research extends existing heuristic inspection with criteria grids to include emotional and persuasiveness factors. We first review the existing criteria and categorize them into four major groups, aligned along a historic perspective of HCI. Hence, we find criteria that fall into (a) accessibility, (b) usability, then (c) affective, and finally (d) persuasive categories. In the second part of the paper, we focus on heuristic inspection based on persuasive criteria. We show their importance and apply them to the example of an e-learning platform for college mathematics. Results of the heuristic inspection of the persuasive factors are reported along with their prescribed recommendations.
\end{abstract}

Keywords: Persuasive technology, Heuristic inspection, Ergonomics criteria, E-learning.

\section{Heuristic Inspection and the Evaluation of Hci}

The field of ergonomics has produced numerous guidelines to measure the quality of interfaces. But in the field of persuasive technology, the idea to evaluate persuasion is not yet commonplace. Our approach is to define guidelines to measure and assess the persuasive dimensions of user experiences. These guidelines provide heuristics on persuasion that experts in User Experience can use during the evaluation and design processes.

A heuristic is a general principle that can guide a design decision or be used to assess the quality of a design decision in an existing interface. Heuristic evaluation has been developed as a method for conducting the assessment of a system using a set of simple and general heuristics. The general idea behind heuristic evaluation is that user experience (UX) specialists independently assess interfaces to identify potential problems. Heuristic evaluation is best used as a cost and time effective evaluation technique. However, existing criteria grids typically do not address persuasion factors in interfaces. Hence the goal to develop a method of heuristic inspection dedicated to persuasion. 
The influence of emotional and persuasive factors towards the success and failure of user interfaces is gaining stronger recognition. In addition to the recent explosion of social and commercial web sites that need to attract and retain their user base, elearning applications is another family of applications that rely on their effectiveness to engage their users in a learning process. We focus on one such application to demonstrate the proposed persuasion criteria grid and evaluate its capacity to help suggest improvements to the e-learning application interface. This application is a self-regulated exerciser in college mathematics. Students are left completely free to use this exerciser or not, and therefore the potency of its user interface to motivate and convince the student to use it paramount in this context.

\section{Heuristic Inspection Framework: from Accessibility Criteria to Usability, Pleasure and Persuasiveness Criteria}

The use of criteria for heuristic inspection of user interfaces can be traced back over the last 50 years of so of technology evolution [1]. Fig. 1 schematically illustrates the historical co-evolution.

Early criteria in the 1960s were defined for making computers accessible to individuals with special needs. The criteria addressed a set of psychophysiological and biomechanical constraints adapted to physiological or mental human characteristics. A recent example of well known accessibility criteria is the Web Content Accessibility Guidelines from W3C/WAI.

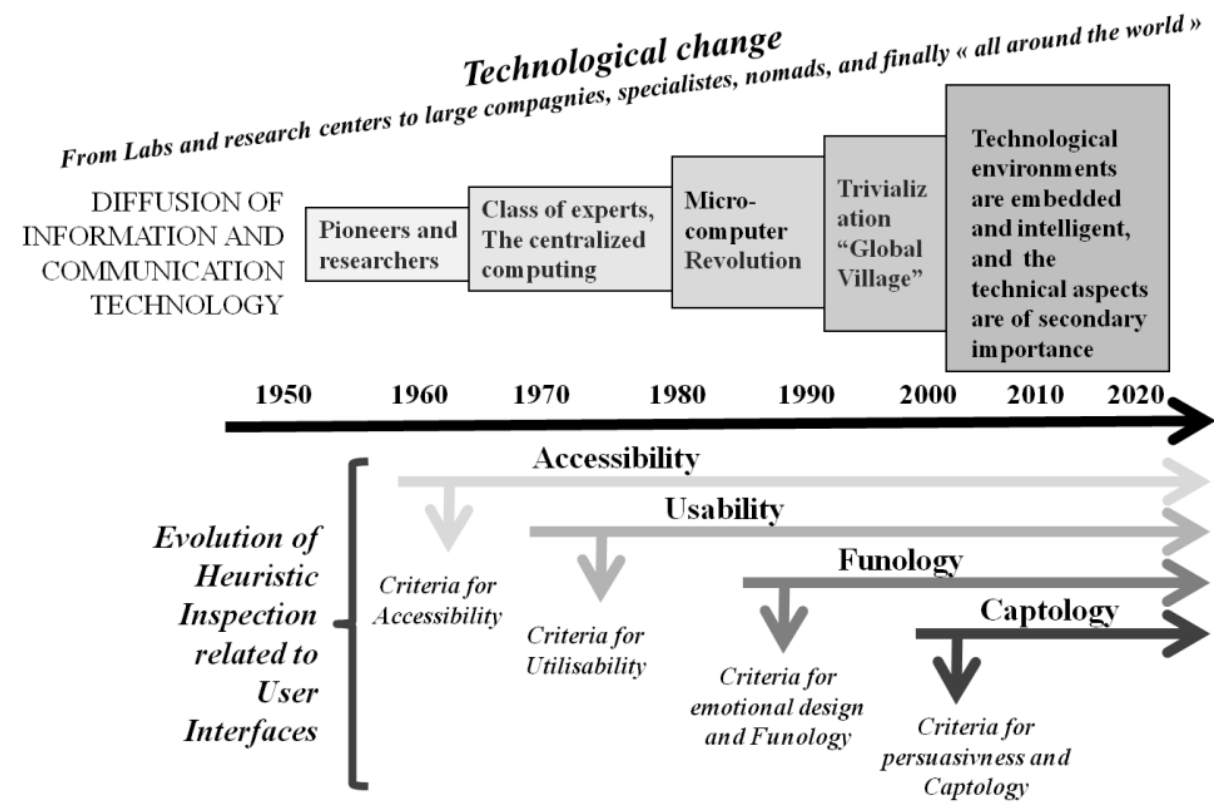

Fig. 1. Criteria for heuristic inspection and the development of information and communication technologies. 
The 1970's saw the emergence of usability concerns. They were eventually cast into standards such as ISO 9241-11, and in design and evaluation heuristics such as[4, $9,12]$.

The evaluation criteria of standards and heuristics aimed to provide design guidelines and evaluation tools. They specifically aim to empower the user to perform tasks in an efficient and fluent manner. However, they did not address the affective and emotional dimensions of HCI, in particular factors that affect user engagement and motivation to use an application such as aesthetics, social value and prestige, social interaction, sense of accomplishment, self expression, and learning.

Interestingly, the affective and emotional criteria are sometimes at odds with usability criteria. For example, aesthetics can influence the mood of a user and positively affect his likeliness to buy a product on a site, but the positive effect may be offset if the aesthetic is emphasized at the expense of usability.

The persuasive dimension addresses the motivational factors of HCI. Fogg [3] defines persuasion as "An attempt to change attitudes or behaviors or both (without using coercion or deception)" (Fogg, 2003, p. 15). Persuasive technology aims to capture the user's attention and to maintain the will to interact. A long list of design patterns and principles can be deployed to help tunnel user behaviour towards specific target either witin a human-computer interaction [3] or a computer mediated humanhuman interaction [11].

The next section addresses the goal of evaluating, through the use of a criteria grid, the quality and effectiveness of an interface.

\section{$3 \quad$ Heuristics to Inspect Persuasion in Interfaces}

Effective persuasion rests upon motivational and cognitive factors. We first review the theoretical foundations of the persuasive mechanisms at stake and then describe the criteria that derive from this framework.

\subsection{Persuasion Indicators and Persuasive Technology Means}

Oinas-Kukkonen \& Harjumaa [11] define four types of persuasive design means. They are the support means for the (a) task, (b) interaction dialog, (c) social interaction and (d) credibility.

- Task support. To bring the user towards the target behaviour, task support should be provided through interface facilitators, which can take the form of attractive icons and images, personalized messages, repeated messages and a suggestive sequence of interactions. Task support design principles are:

- Reduction: streamline the steps towards the desired behaviour.

- Tunneling: progressively constrain the path to the desired behaviour.

- Tailoring and personalization: adapt the information displayed to user needs, interest, personality or context of use. 
- Self-monitoring: monitor progress towards desired goal and provide support when

- Simulation: provide simulations to allow observation of the causal relationship of a given behavior.

- Rehearsal: allow the user to repeat a given behaviour

- Dialog support. Techniques to initiate dialog and forster its continuation:

- Praise: positive feedback in words, images, symbols or sound.

- Rewards: reward desired behaviour.

- Reminders: provide continuous reminder or desired behaviour.

- Suggestion: display timely and relevant behaviour suggestions.

- Similarity: use similarity with established system.

- Liking: attractive look.

- Social role: associate a social role to the system.

- Social support. Facilitate interaction with like-minded people and avoid contact with people of diverging values. Social support encourages behaviour rationalization, in particular for situations of cognitive dissonance.

- Social learning: allow users to observe peer behaviour of peers and learn about social conducts and their consequences.

- Social comparison: allow user to compare their behaviour with other and foster perseverance.

- Normative influence: leverage social pressure to induce target behaviours.

- Social facilitation: leverage the tendency of individuals to initiate and persist in desired behaviours if they feel observed or if a peer is also involved in parallel conduct.

- Cooperation: leverage the natural tendency of individuals to collaborate.

- Competition: leverage the natural tendency of individuals to compete.

- Recognition: provide a group or an individual a public recognition of merit for their behaviour.

- System credibility. Credibility is key to social influence. A system that provides incorrect information or, for some reason, loses its credibility can be permanently disabled to exert any kind of persuasion.

- Trustworthiness: induce a perception of good intention, high moral values, and unbiased communication.

- Expertise: perception as a knowledgeable and competent source of information.

- Third-party endorsement: show that the system has outside support.

- Surface: the visual look must support the impression of competence.

- Real-world feel: show that an organisation and a team is behind the system.

- Authority: make references to authoritative sources.

- Verifiability: allow information to be cross-verified.. 


\subsection{Persuasiveness Criteria Grid}

The above framework is behind the Nemery, Brangier and Kopp [8,9] criteria grid for persuasion inspection. The grid rests on the general technique of inspection. To inspect the usability of a product, whether a user interface or any artefact designed to be used by some user, is to make a judgement about its ability to be effective, efficient, error-tolerant, easy to learn and satisfying. This judgement is made by experts in ergonomics or HCI. Inspections are often the method of choice to quickly target usability issues and find the proper corrections to bring to the design of an application. As a result, the guidelines purpose is to measure the persuasive dimensions involved in interface, to help experts to evaluate the interface using these criteria.

The Persuasiveness criteria grid $[8,9]$ follows from the review of 164 papers in the field of captology and PT. Eight criteria were deemed sufficient to encompass the persuasiveness factors: credibility, privacy, personalization, attractiveness, solicitation, initiation, commitment and ascendency [6]. These criteria are grouped under static and dynamic categories (see Table 1):

- Static criteria are prerequisite elements to establish a fertile context within which a dynamic process of persuasion can be launched. These elements pro-mote the acceptance of a persuading process.

- Dynamic criteria are involved in a process designed to engage the user in a series of planned and ordered persuasive steps in which the temporal factor is critical. At each step of the behavioral changes, elements of the interface bring the user to commit to greater levels of engagement.

\section{$4 \quad$ A Case Study for the Criteria Grid}

In an effort to assess the Persuasiveness criteria grid, we analyze an e-learning application using this grid. The software over which the grid is applied is designed as a drill and practice learning environment on the topic of college mathematics. We will refer to it as the Exerciser. The Exerciser was inspected by the two authors who are $\mathrm{HCI}$ and e-learning experts. In the final communication, we will provide insights on the application of the grid.

\subsection{The Application Domain: College Mathematics for Freshman Engineers}

Mathematics is often a source of difficulty in the first year of an engineering program. To help newly enrolled students ensure they have the expected mastery of all prerequisites in math for the first year courses, Polytechnique Montreal developed the Exerciser which contains over 1000 exercices [5]. All of the approximately 1000 newly enrolled students were invited to test their knowledge with an online test and they were thereafter invited to use the Exerciser if they wished. No other incentive to use it was given.

In its first deployment in the spring-summer of 2012, only a few tens of students used it, from a few minutes up to over 100 hours for a few cases. The high rate of 
students who did not pursue over a few minutes led us to consider that it was a good case to apply persuasive technology to encourage students using the Exerciser more extensively.

\subsection{Exerciser Interface Screens}

The Exerciser interface is composed of eight types of screens:

- Welcome page,

- Confidenciality agreement and consent,

- General explanation page,

- Exercise pages (1040 exercises shown between 2 to 5 at a time),

- A dialog window for the solution to each exercise,

- Class notes (equivalent to approx. 150 pages in print); navigation from a topic of the class notes to the corresponding exercises, and back, is available throughout the notes,

- Summary results page showing completed exercises,

- Online help page.

These eight screen types were inspected with the persuasion criteria grid in order to identify strong and weak features (fig. 2 and 3).

\subsection{Screen Inspections}

The results of the eight screen categories persuasion inspection are reported in table 2 . For each screen category, the two experts estimated the persuasive quality over the eight criteria and 23 sub-criteria. Table three contains the global compilation along the eight criteria.

The credibility and privacy criteria are generally met with success by the Exerciser [2]. The application is expected to inspire trust.

However, the interactive dialog is not personalized, the interface is not particularly attractive visually, and we find very few solicitations and interactions priming. The prospects of engaging the user to interact are weak.

Ascendency, the most extreme measure of persuasiveness, does not appear to be present at all. 
Table 1. The eight persuasive interactions criteria of Nemery et al. (2011)

\begin{tabular}{|c|c|c|c|}
\hline \multicolumn{2}{|c|}{ Criteria } & Definitions & Sub-criteria \\
\hline \multirow{4}{*}{ : } & $\begin{array}{l}\text { Credibil- } \\
\text { ity }\end{array}$ & $\begin{array}{l}\text { is the ability of the interface to inspire confidence and to } \\
\text { make the user confident in the veracity of its infor- } \\
\text { mation. Credibility is based on reputation and notoriety. }\end{array}$ & $\begin{array}{l}\text { Trustwothiness. } \\
\text { Expertise. } \\
\text { Fidelity. } \\
\text { Legitimity. }\end{array}$ \\
\hline & Privacy & $\begin{array}{l}\text { refers to the protection of personal data and the preserva- } \\
\text { tion of personal integrity and security of the interaction. } \\
\text { It also refers to protection against loss, destruction or } \\
\text { inadvertent disclosure of this data. }\end{array}$ & $\begin{array}{l}\text { Safeness. } \\
\text { Law respect } \\
\text { feeling. } \\
\text { Confidentiality. }\end{array}$ \\
\hline & $\begin{array}{l}\text { Personal- } \\
\text { ization }\end{array}$ & $\begin{array}{l}\text { refers to the concept of customization of the interface to } \\
\text { the needs of the user. The customization can be a greet- } \\
\text { ing, a promotion, or any means to achieve a more per- } \\
\text { sonal interaction with the user. It may also rely on group } \\
\text { membership. }\end{array}$ & $\begin{array}{l}\text { Individualiza- } \\
\text { tion. } \\
\text { Group member- } \\
\text { ship. }\end{array}$ \\
\hline & $\begin{array}{l}\text { Attrac- } \\
\text { tiveness }\end{array}$ & $\begin{array}{l}\text { is the use of aesthetics (graphic, art, design) to capture } \\
\text { the attention of the user, to support the interaction and } \\
\text { create a positive emotion. The animation, colors, menus, } \\
\text { drawings, video films are designed to catch and maintain } \\
\text { the interest of the user. }\end{array}$ & $\begin{array}{l}\text { Emotional at- } \\
\text { traction. } \\
\text { Call to action. } \\
\text { Tunneling de- } \\
\text { sign. }\end{array}$ \\
\hline \multirow{4}{*}{ 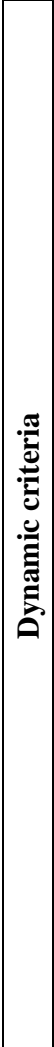 } & $\begin{array}{l}\text { Solicita- } \\
\text { tion }\end{array}$ & $\begin{array}{l}\text { is the first of the four dynamic criteria. It refers to the } \\
\text { initial stage which aims to swiftly attract and challenge } \\
\text { the user to initiate the relationship. The interface at- } \\
\text { tempts by words, graphics, or any form of dialogue, to } \\
\text { suggest a behavior and induce action through minimal } \\
\text { influence. }\end{array}$ & $\begin{array}{l}\text { Allusion. } \\
\text { Suggestion. } \\
\text { Teasing. }\end{array}$ \\
\hline & Initiation & $\begin{array}{l}\text { refers to elements of the media that entice the first user- } \\
\text { initiated actions. The user's attention is captured and, } \\
\text { through his own initiative, encouraged to realize the first } \\
\text { engaging action. The user is caught in a gradual engage- } \\
\text { ment process. }\end{array}$ & $\begin{array}{l}\text { Priming. } \\
\text { First action } \\
\text { guidance. }\end{array}$ \\
\hline & $\begin{array}{l}\text { Com- } \\
\text { mitment }\end{array}$ & $\begin{array}{l}\text { means that system further involves the user in a process. } \\
\text { Several queries and incentives regularly and gradually } \\
\text { engage the user. The electronic media will induce more } \\
\text { intensive and regular behavior. }\end{array}$ & $\begin{array}{l}\text { Repeated re- } \\
\text { quest. } \\
\text { External nega- } \\
\text { tive factor } \\
\text { avoidance. } \\
\text { Increased cost. }\end{array}$ \\
\hline & $\begin{array}{l}\text { Ascend- } \\
\text { ency }\end{array}$ & $\begin{array}{l}\text { is an expression of the completion of the engaging sce- } \\
\text { nario. The user has unequivocally accepted the logic and } \\
\text { goals of the media. The interaction is characterized by } \\
\text { induced pleasure and possibly by the relief of internal } \\
\text { discomfort. Ascendency is closely related to the concept } \\
\text { of immersion in the video game field and it implies a } \\
\text { high level of repetition and regularity of interaction, and } \\
\text { sometimes emotional involvement in the story that re- } \\
\text { sults in dependence and game character identification. } \\
\text { Users develop emotional attachment and cannot envision } \\
\text { themselves without these products, or would feel a sub- } \\
\text { stantive negative effect in case of loss. }\end{array}$ & $\begin{array}{l}\text { Prescription of } \\
\text { repetition. } \\
\text { No-limit inter- } \\
\text { action. } \\
\text { Pressure re- } \\
\text { leased. }\end{array}$ \\
\hline
\end{tabular}




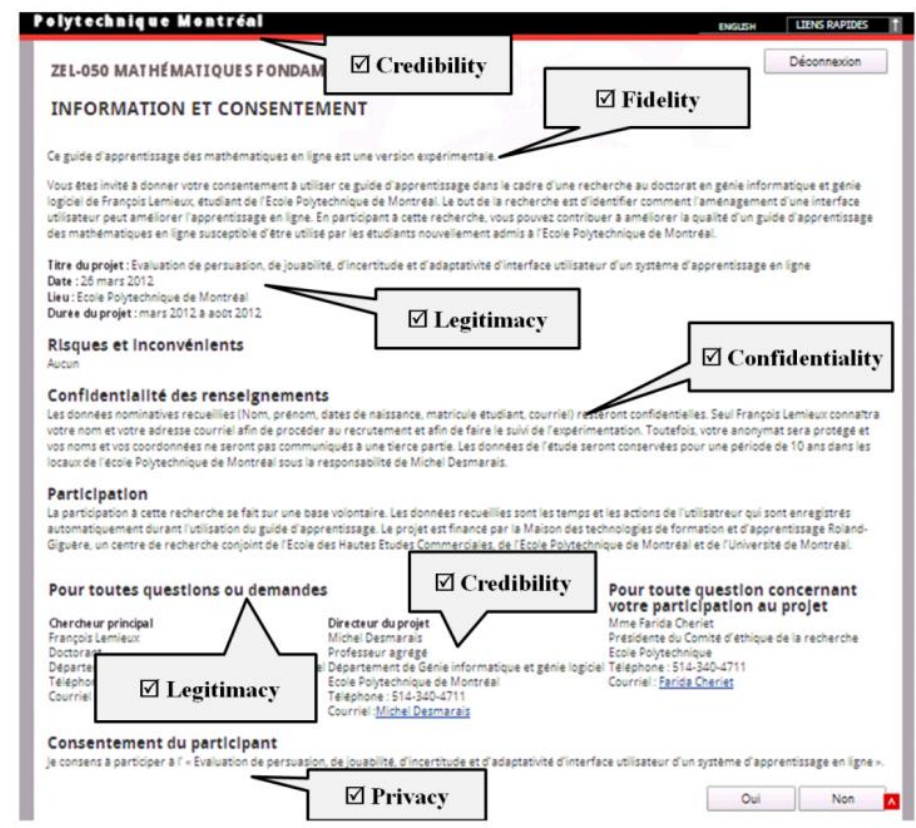

Fig. 2. Some good examples of persuasion issues of the Exerciser.

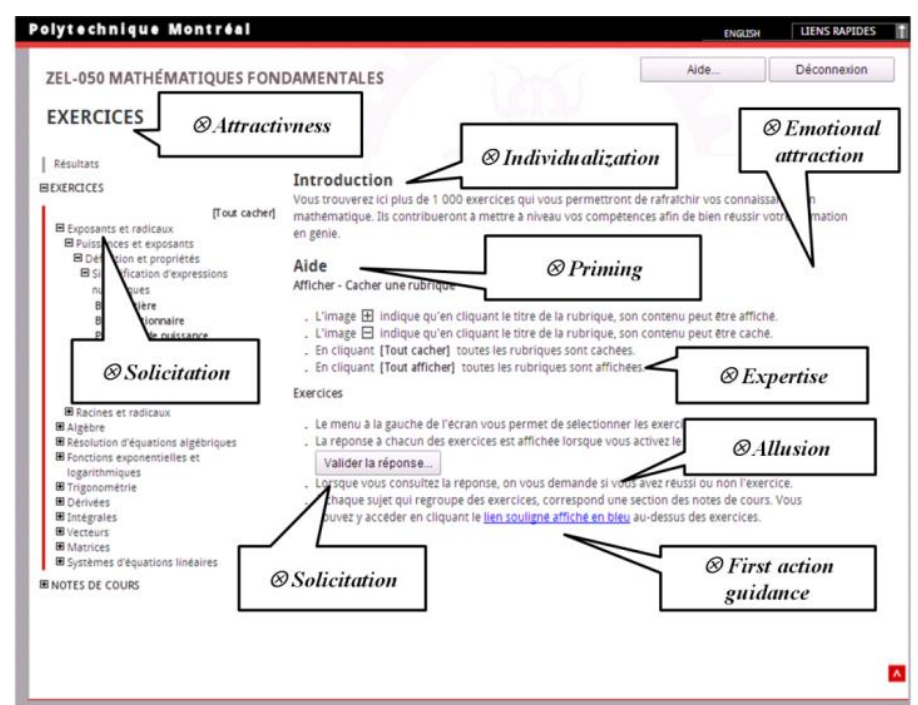

Fig. 3. Some bad examples of persuasion issues of the Exerciser. 
Table 2. Results of the inspection with the persuasive criteria grid for all eight screen types.s

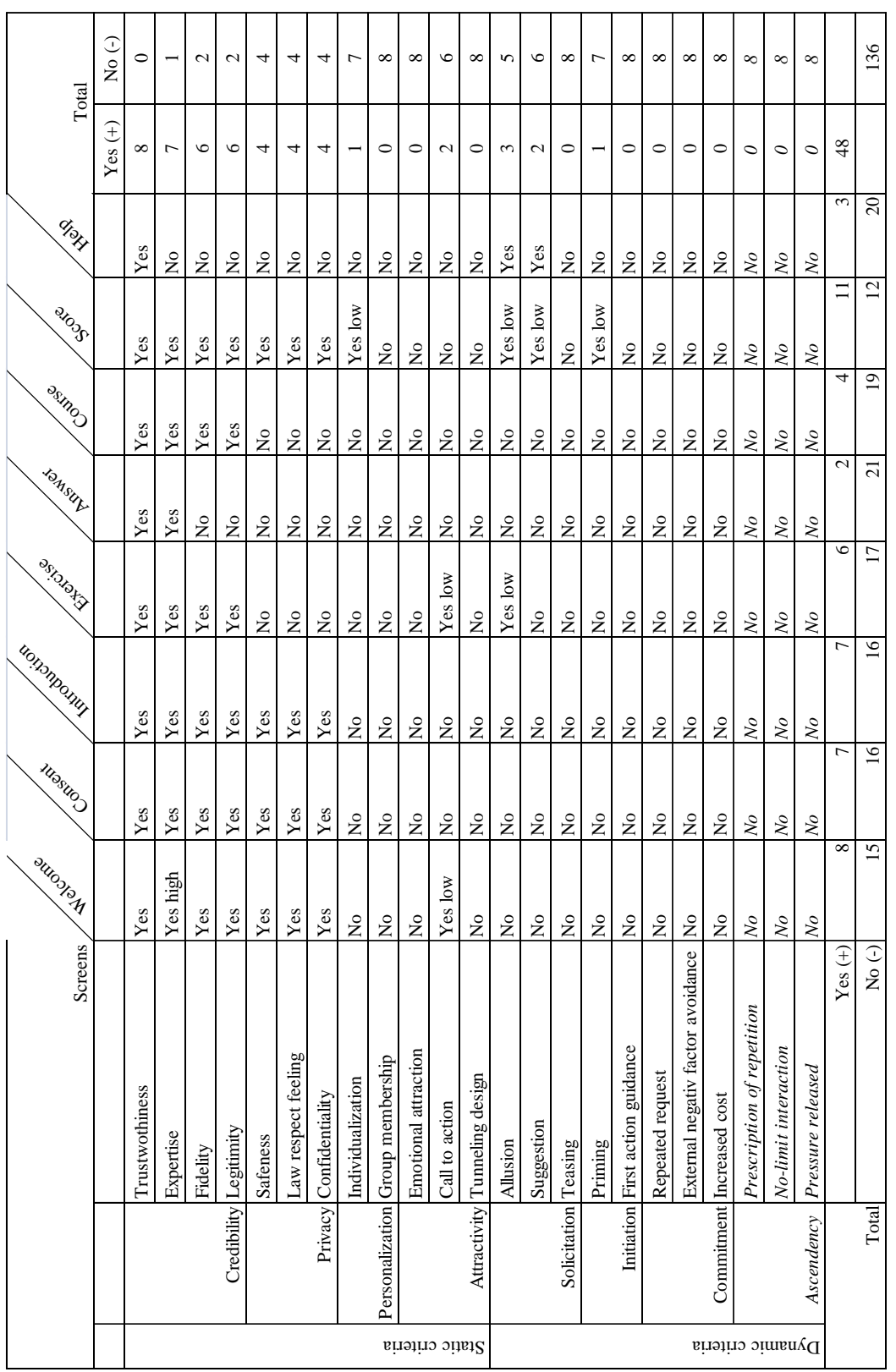




\section{Recommendations and Perspectives}

Table 3 summarizes the results of Table 2 on a per criteria basis. It reveals the weaker points of the Exerciser's interface, namely personalization, commitment, initiation, attractiveness, and solicitation. Table 4 lists some of the specific problems and their corresponding remedial recommendations that follow from the inspection results.

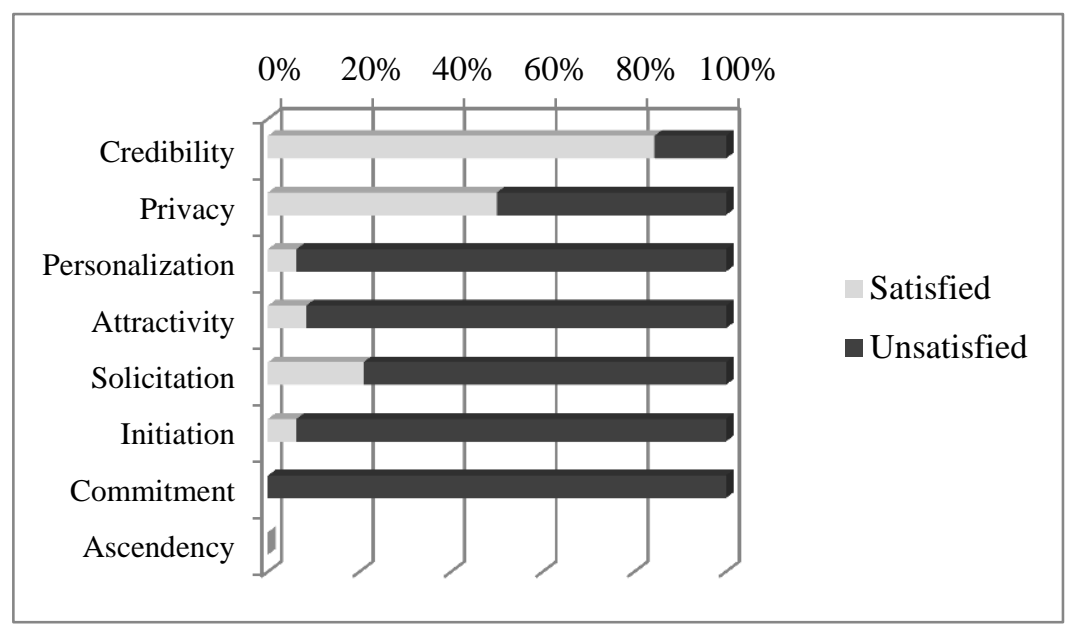

Table 3. Globalization of the scores of each persuasive criteria (Ascendancy is not relevant in the case of educational interfaces).

We claim that, akin to the heuristic inspection of an interface's usability, persuasion can be subjected to heuristic inspection and that the results will help guide the design of persuasive interfaces. Through iterative prototyping, they allow the development of more effective persuasive technology, especially in the early stages of development, when prototypes are too rudimentary for user testing.

E-learning applications are well suited applications for leveraging persuasiveness. Engaging the student in a learning process can definitely benefit from persuasive technology principles. We rely on inspection grid to assess the persuasiveness of elearning systems and apply it over an existing e-learning environment to gather concrete experience on how appropriate it is in the specific context of e-learning. 


\begin{tabular}{|c|c|}
\hline General ideas & Examples \\
\hline $\begin{array}{l}\text { Personalization: Improve the customization } \\
\text { aiming to adapt the interface to the needs of } \\
\text { individual ownership from the user. The } \\
\text { customization includes all actions aimed at } \\
\text { characterizing a greeting, a picture, a badge } \\
\text { or a context to achieve a closer approach the } \\
\text { user. As any users, the learner want services } \\
\text { tailored to their needs and learning. }\end{array}$ & $\begin{array}{l}\text { A lack of customization may cause a lack of } \\
\text { interest in interaction. } \\
\text { A personalized welcome will challenge the } \\
\text { user. } \\
\text { Give the user the ability to select the charac- } \\
\text { teristics of its screens makes the user more } \\
\text { receptive to influences. } \\
\text { A proposal that reflects and complements } \\
\text { previous exercises will be experienced as a } \\
\text { personalized proposal. }\end{array}$ \\
\hline $\begin{array}{l}\text { Attractiveness: Improve the use of aesthetics } \\
\text { (colors, graphic, art, design) to capture the } \\
\text { attention of the user, to support the interac- } \\
\text { tion and create a positive emotion. Persuasive } \\
\text { design could motivate users towards specific } \\
\text { actions. }\end{array}$ & $\begin{array}{l}\text { The animation, colors, menus, drawings, } \\
\text { video films are designed to catch and main- } \\
\text { tain the interest of the user. } \\
\text { The conformity between the text and images } \\
\text { reinforce attractiveness. } \\
\text { The use of a virtual agent could increase the } \\
\text { seduction of the user. }\end{array}$ \\
\hline $\begin{array}{l}\text { Solicitation: Improve the first stage, which } \\
\text { aims to briefly attract and challenge the user } \\
\text { to start exercises. The invitation sets up the } \\
\text { beginning of the relationship and the dialogue } \\
\text { between the user and web exercises. }\end{array}$ & $\begin{array}{l}\text { When broadly disseminated, the first person- } \\
\text { alized message increases the probability of } \\
\text { initiating the first action from the user. } \\
\text { Highlight attractive messages for the website } \\
\text { to encourage users to click on a link... and } \\
\text { learn math. }\end{array}$ \\
\hline $\begin{array}{l}\text { Initiation/Priming: Improve elements of the } \\
\text { media that triggers the persuasive influence. } \\
\text { These elements may take the form of piloting } \\
\text { the first steps. With initiation, the first action } \\
\text { is done without coercion or perception, }\end{array}$ & $\begin{array}{l}\text { Organize interactions where the user is } \\
\text { caught in a process that grabs him gradually. } \\
\text { Complete simple exercises, which give you } \\
\text { congratulations, badges or social awards. }\end{array}$ \\
\hline $\begin{array}{l}\text { Commitment: Improve the capacity of the } \\
\text { system continues to involve user through an } \\
\text { engaging process. } \\
\text { It is the set up of action sequences or prede- } \\
\text { termined situations. }\end{array}$ & $\begin{array}{l}\text { Organize queries, questions, exercises, mes- } \\
\text { sages regularly and gradually which involve } \\
\text { the user. } \\
\text { Repeat to the user to get in touch with other } \\
\text { students in order to strengthen the infor- } \\
\text { mation on a social network related to math. }\end{array}$ \\
\hline
\end{tabular}

Table 4. Some recommendations stemming from the persuasion inspection

\section{References.}

1. Brangier, E. \& Bastien, J-M-C. (2010). Ergonomie des produits informatiques : faciliter l'expérience utilisateur en s'appuyant sur les notions d'accessibilité, utilisabilité, émotionnalité et d'influençabilité. In G. Vallery, M. Zouinar \& M-C Leport. (Eds) Ergonomie, conception, de produits et services médiatisés, PUF, 307-328. 
2. Brangier, E., \& Desmarais, M. (2013). The design and evaluation of the persuasiveness of e-learning interfaces. International Journal of Conceptual Structures and Smart Applications. Special issue on Persuasive Technology in Learning and Teaching. 1(2), 38-47, JulyDecember 2013.

3. Fogg, B. J. (2003). Persuasive Technology: Using Computers to Change What We Think and Do. San Francisco: Morgan Kaufmann.

4. Jordan, P.W. (1998). An introduction to usability. London : Taylor \& Francis.

5. Lemieux, F., Desmarais, M. C., \& Robillard, P.-N. (2013). Motivation et analyse chronologique des traces d'un exerciseur pour l'auto-apprentissage. Sciences et Technologies de l'Information et de la Communication pour L'Education et la Formation (STICEF), (accepted).

6. Némery, A. \& Brangier, E. (2011). Criteria grid for persuasive interfaces. Retrieved October $2013 \mathrm{http}: / /$ www.univ-metz.fr/ufr/sha/2lp-etic/Criteres_Persuasion_Interactive-2.pdf

7. Némery, A., Brangier, E., \& Kopp, S. (2010). Proposition d'une grille de critères d'analyses ergonomiques des formes de persuasion interactive In B. David, M. Noirhomme et A. Tricot (Eds) Proceedings of IHM 2010, International Conference Proceedings Series, New-York: ACM, 153-156..

8. Némery, A., Brangier, E., \& Kopp, S. (2011). First validation of persuasive criteria for designing and evaluating the social influence of user interfaces: justification of a guideline. In A. Marcus (Ed.): Design, User Experience, and Usability, LNCS 6770, pp.616-624.

9. Nielsen, J. (1994). Heuristic Evaluation. In J. Neilsen \& R.L. Mack (Eds), Usability Inspection Methods, New York: John Wiley \& Sons, Inc.

10. Oinas-Kukkonen, H. (2010). Behavior Change Support Systems: A Research Model and Agenda. In T. Ploug, Per Hasle, \& H. Oinas-Kukkonen (Eds.), Proceedings of the 5th International Conference on Persuasive Technology - Persuasive '10. Berlin, Heidelberg: Springer-Verlag.

11. Oinas-Kukkonen, H., \& Harjumaa, M. (2009). Persuasive Systems Design: Key Issues , Process Model, and System Features. Communications of the Association for Information Systems, 24(1), 485-500.

12. Scapin, D.L., \& Bastien, J.M.C. (1997). Ergonomic criteria for evaluating the ergonomic quality of interactive systems. Behaviour and information technology, 16, 220-231. 